CLINICAL HEMORHEOLOGY, Vo1. 9, pp. 167-172, 1989

$0271-5198 / 89 \$ 3.00+.00$ Printed in the USA.

Copyright (c) 1989 Pergamon Press plc. All rights reserved.

\title{
CLINICAL HEMORHEOLOGY - LITERATURE SURVEY
}

\author{
Editor: E. Ernst
}

The key words were chosen for this section by the Editor. The English titles, given in brackets, are usually the translations by the authors. The asterisk (*) indicates the name of the author to whom requests for reprints should be addressed.

The statment "No address available" indicates, that it did not appear on the computer printout consulted by the Editor.

The Readers of our Journal are encouraged to send information regarding their own publications in journals other that CLINICAL HEMORHEOLOGY and BIORHEOLOGY to E. Ernst (address see cover) and, if possible, reprints as well.

ANEZAKI, $K$. Research on oxygen transport in jaw cysts: investigation of changes of erythrocyte membrane fluidity. Adv. Exp. Med. Biol. 222: 647-653, 1988.

Key words: erythrocyte membrane, membrane fluidity, mouth diseases, oxygen Address for reprints: Department of Dentistry and Oral Surgery, School of Medicine, Hirosaki University, Japan.

CACIOLI, D.*, CLIVATI, A., PELOSI, P., MEGEVAND, J. and GALEONE, M. Haemorheological effects of fructose-1,6-diphosphate in patients with lower extremity ischaemia. Curr. Med. Res. Opin. 10: 668-674, 1988.

Key words: arterial occlusive diseases, blood viscosity, erythrocyte deformability, erythrocyte aggregation

Address for reprints: Second Surgical Division, Sesto S. Giovanni Hospital, Milan, Italy.

CHEN, J.F. A hemorrheological study on the effect of acupuncture in treating diabetes mellitus. J. Tradit. Chin. Med. 7: 95-100, 1988.

Key words: acupuncture, diabetes mellitus, blood viscosity No address available.

CHENG, S.* and CHEN, Y.L. Study on erythrocyte membrane fluidity by laser Raman spectroscopy. Cell Ciol. Int. Rep. 12: 205-211, 1988.

Key words: coronary disease, erythrocyte membrane, liver cirrhosis, nephrotic syndrome

Address for reprints: Department of Biophysics, Beijing Medical University, Japan. 
CiUfFETTI, G.*, MERCURI, M., PARNETTI, L., LUPATTELLI, G. and SENIN, U. Hemorheologic factors in the postacute phase of ischemic stroke. Angiology 437-448, 1988.

Key words: ischemic stroke, red blood cell deformability, hematocrit

Address for reprints: 2nd Department of Internal Medicine, Gerontologic and Geriatric Chair, Faculty of Medicine, University of Perugia, Italy.

COPLEY, A.L. Robert Gwyn Macfarlane's contribution to the organization of biorheology - and other reminiscences. Thromb. Res. 49: 153-156, 1988.

Key words: hematology, rheology, historical biography

Address for reprints: Polytechnic University, Brooklyn, New York, NY 11201, USA.

CORTINOVIS, A.*, CRIPPA, A., SCIACCA, V., CARAVAGGIO, V. and CRIPPA, M. Modificazioni emoreologiche, metagolich ed emocoagulative in diabetici in trattamento con sulfaniluree (Hemorheologic, metabolic and blood coagulation changes in diabetics in treatment with sulfanyl ureas). Minerva Med. 79: $391-398,1988$.

Key words: blood coagulation, diabetes mellitus, sulfonylurea (English abstract)

Address for reprints: Universita di Pavia, Semeiotica Medica, IRCCS, Policlinico San Matteo, Departimento di Medicina Interna e Terapia Medica, Italy.

CORTINOVIS, A.*, CRIPPA, A., SCIACCA, V. and CARAVAGgIO, V. Emoreologia e variazioni acute "in vivo" di fattori sierici non viscosi (Hemorheology and acute in vivo changes in non-viscous serum factors). Minerva Med. 79: $355-366,1988$.

Key words: blood viscosity, electrolytes, hemodialysis, chronic kidney failure (English abstract)

Address for reprints: as above.

CORTINOVIS, A.*, CRIPPA, A., SCIACCA, V. and CARAVAGGIO, V. Presentazione di un metodo di interpretazione della deformabilita eritrocitaria (Prensentation of a method of interpreting erythrocyte deformability). Minerva Med. 79: 343-348, 1988.

Key words: blood viscosity, erythrocyte deformability, hemofiltration (English abstract)

Address for reprints: as above.

DE ANGELIS, V., ORAZI, B.M., SANTAROSA, L. and MOLARO, G. Erythrocyte shape control in stored blood: the effect of additive solutions on shape recovery. Haematologica (Pavia) 73: 7-12, 1988.

Key words: anticoagulants, blood preservation, erythrocyte deformability No address available.

EHRLY, A.M.*, LANDGRAF, H., HESSLER, J. and SÄGER-LORENZ, K. Influence of videofilm-induced emotional stress on the flow properties of blood. Angiology 39: 341-344, 1988.

Key words: blood viscosity, psychological stress, heart rate, vascular resistance

Address for reprints: Department of Internal Medicine, J.W.-Goethe-University Clinic, 6000 Frankfurt/Main, FRG. 
ERNST, E.*, KOENIG, W., MATRAI, A., FILIPIAK, B., STIEBER, J. Blood rheology in healthy cigarette smokers. Results from the MONICA project, Augsburg. Arteriosclerosis 8: 385-388, 1988.

Key words: blood viscosity, smoking, blood proteins

Address for reprints: Hemorheology Research Laboratory, Department of - Physical Medicine, University of Munich, Ziemssenstr. 1, 8000 Munich 2, FRG.

ERNST, E.*, MATRAI, A. and MARSHALL, M. Blood rheology in patients with transient ischemic attacks. Stroke 19: 634-636, 1988.

Key words: transient cerebral ischemia, blood viscosity Address for reprints: as above.

FORTIER, N.*, SNYDER, L.M., GARVER, F., KIEFER, C., MCKENNEY, J. and MOHANDAS, $N$. The relationship between in vivo generated hemoglobin skeletal protein complex and increased red cell membrane rigidity. Blood 71: 1427-1431, 1988.

Key words: erythrocyte deformability, hemoglobins, sickle cell anemia Address for reprints: Department of Hematology, St. Vincent Hospital, Worcester, MA 01604, USA.

FRANK, R.S.* and HOCHMUTH, R.M. The influence of red cell mechanical properties on flow through single capillary-sized pores. J. Biomech. Eng. 110: 155-160, 1988.

Key words: blood flow velocity, erythrocyte deformability, capillaries

Address for reprints: Departent of Biomedical Engineering, Duke University, Durhan, N.C. 27706, USA.

GARNIER, M.*, PERRET, G., PILARDEAU, P., VAYSSE, J., ROLLAND, Y., UZZAN, B. and VASSY, R. Effect of diosmin upon red blood cell deformability and osmotic fragility. Relationship with lipid content. Methods Find. Exp. Clin. Pharmacol. 10: 259-262, 1988.

Key words: erythrocyte deformability, diosmin, osmotic fragility, phospholipids

Address for reprints: University of North Paris, School of Medicine, Laboratory of Experimental and Clinical Pharmacology, Bobigny, France.

GRENNE, M.A.*, NOGUCHI, C.T., KEIDAN, A.J., MARWAH, S.S. and STUART, J. Polymerization of sickle cell hemoglobin at arterial oxygen saturation impairs erythrocyte deformability. J. Clin. Invest. 81: 1669-1674, 1988.

Key words: sickle cell anemia, erythrocyte deformability, oxygen Address for reprints: Department of Haematology, Medical School, University of Birmingham, U.K.

HAKIM, T.W.* and MACEK, A.S. Role of erythrocyte deformability in the acute hypoxic pressor response in the pulmonary vasculature. Respir. Physiol. 72: 96-107, 1988.

Key words: anoxia, erythrocyte deformability, pulmonary circulation, vascular resistance

Address for reprints: Department of Physiology, MCGill University, Montreal, Quebec, Canada. 
HARTMANN, A.* and TSUDA, Y. A controlled study on the effect of pentoxifylline and an ergot alkaloid derivative on regional cerebral blood flow in patients with chronic cerebrovascular disease. Angiology 449-457, 1988.

Key words: cerebral blood flow, chronic cerebrovacular disease, pentoxifylline

Address for reprints: Neurologische Universitätsklinik Bonn, FRG.

HSU, C.Y.*, NORRIS, J.W., HOGAN, E.L., BLADIN, P. et al. Pentoxifylline in acute nonhemorrhagic stroke. Stroke 19: 716-722, 1988.

Key words: cerebral infarction, pentoxifylline, clinical trials

Address for reprints: Department of Neurology, Medical University of South Carolina, Charleston, SC 29425, USA.

ITO, T.* and KON, H. A flOW EPR study of deformation and orientation characteristics of erythrocyte ghosts: a possible effect of an altered state of cytoskeletal network. J. Membr. Biol. 101: 57-65, 1988.

Key words: cytoskeleton, erythrocyte deformability

Address for reprints: Laboratory of Chemical Physics, National Institute of Diabetes and Digestive and Kidney Diseases, Bethesda, Maryland 20892, USA.

JUNG, M.*, KOPPENSTEINER, R., GRANINGER, W., MINAR, E., KRETSCHMER, G. and EHRINGER, H. Hämorheologie und Akute-Phase-Reaktion nach Thrombendarteriektomie der extracraniellen Arteria carotis (Hemorheology and acute phase reaction following thrombendarterectomy of the extracranial carotid artery). Klin. Wochenschr. 66: 379-384, 1988.

Key words: carotid artery thrombosis, cerebrovascular circulation, postoperative complication, acute phase reaction (English abstract)

Address for reprints: Angiologische Abteilung, 1. Medizinische Universitätsklinik, Wien, Austria.

KUMMER, R. v.*, SCHARF, J., BACK, T., REICH, H., MACHENS, H.G. and WILDEMANN, B. Autoregulatory capacity and the effect of isovolemic hemodilution on local cerebral blood flow. Stroke 19: 594-597, 1988.

Key words: autoregulation, cerebral blood flow, hemodilution

Address for reprints: Neurologische Univ.-Klinik, Im Neuenheimer Feld 400, 6900 Heidelberg, FRG.

LUO, G. Effects of ligustrazin and anisodamine on whole blood viscosity and erythrocyte deformability in rabbits. Chung Hua I Hsueh Tsa Chih 67: 607-609, 1987.

Key words: blood viscosity, fibr inolytic agents, vasodilator No address available.

MAEDA, N.*, SEIKE, M., KON, K. and SHIGA, T. Erythrocyte aggregation as a determinant of blood flow: effect of $\mathrm{pH}$, temperature and osmotic pressure. Adv. Exp. Med. Biol. 222: 563-570, 1988 .

Key words: blood flow velocity, erythrocytes, cell aggregation Address for reprints: Department of Physiology, School of Medicine, Ehime University, Japan.

MIKHAILICHENKO, L.A., REUTOV, M.I., ALEKSANDROV, .N., SHINKARENKO, V.S. and MIKHAILOVA, I.M. Rheologic and morphometric parameters of the microcirculation bed in the rabbit ear following local ischemia. Biull. Eksp. Biol. Med. 105: 407-409, 1988.

Key words: ear, ischemia, microcirculation (English abstract)

No address available. 
NASH, G.B., THOMAS, P.R.S. and DORMANDY, J.A.* Abnormal flow properties of white cells in patients with severe ischaemia of the leg. Brit. Med. J. 296: 1699-1701, 1988.

Key words: abnormal flow properties, white blood cells, ischaemia

Address for reprints: Department of Surgery, St. Jame $s^{i}$ and St. George's Hospitals, London SW128HX, U.K.

RILLAERTS, E.G.*, VERTOMMEN, J.J. and DE LEEUW, I.H. Effect of statil (ICI 128436) on erythrocyte viscosity in vitro. Diabetes 37: 471-475, 1988.

Key words: diabetes mellitus, erythrocyte deformability

Address for reprints: Laboratory for Endocrinology and Nutrition, University of Antwerp, Belgi um.

SCHÖPS, P.*, SEICHERT, N. THIES, W., ERDL, R., SCHATTENKIRCHNER, M. and ERNST, E. Hämorheologische Veränderungen bei chronischer Polyarthritis (Hemorheologic changes in chronic polyarthritis). Z. Rheumatol. 47: 52-57, 1988.

Key words: rheumatoid arthritis, blood viscosity, alpha-macroglobulins (English abstact)

Address for reprints: Department of Physical Medicine, University of Munich, Klinikum Großhadern, Marchioninistr. 15, 8000 München 70, FRG.

SIMPSON, L.O. The etiopathogenesis of premenstrual syndrome as a consequence of altered blood rheology: a new hypothesis. Med. Hypotheses 25: 189-195, 1988.

Key words: blood viscosity, premenstrual syndrome, microcirculation

Address for reprints: Pathology Department, University of Otago, Medical School, Dunedin, New Zealand.

TANGELDER, G.J.*, SLAAF, D.W., ARTS, T. and RENEMAN, R.S. Wall shear rate in arterioles in vivo: least estimates from platelet velocity profiles. Am. J. Physiol. 254: H1059-1064, 1988.

Key words: arteries, blood flow velocity, blood platelets

Address for reprints: Department of Physiology, University of Limburg, Maastricht, The Netherlands.

THIE, A., KUNZE, K. and SPITZER, K. Hämorheologische Behandlung der akuten zerebralen Zirkulationsstörung: Was ist gesichert (Hemorheologic treatment of acute cerebrovascular disorders: what is safe)? Med. Klin. 83: 178-182, 1988.

Key words: cerebrovascular disorders, hemodilution, rheology No address available.

THOMAS, P.R.S., NASH, G.B. and DORMANDY, J.A.* White cell accumulation in dependent legs of patients with venous hypertension: a possible mechanism for trophic changes in the skin. Brit. Med. J. 296: 1693-1695, 1988.

Key words: white cell accumulation, venous hypertension Address for reprints: Department of Surgery, St. James'and St. George's Hospitals, London SW128HX, U.K. 
TSUDA, K.*, TSUDA, S., MINATOGAWA, Y., SHIMA, H., YOSHIKAWA, H., NISHIO, I., KIDO, R. and MASUYAMA, $Y$. Effects of calcium antagonists on membrane fluidity in hypertension - an electron spin resonance study. Am. J. Hypertens. 1: 283-286, 1988.

Key words: diltiazem, electron spin resonance, membran fluidity, hypertension

Address for reprints: Department of Medicine, Wakayama Medical College, Japan.

VERMES, I.* and STRIK, F. Altered leukocyte rheolgy in patients with chronic cerebrovascular disease. Stroke 19: 631-633, 1988.

Key words: cerebrovascular disorders, erythrocyte deformability, leukocytes, chronic disease

Address for reprints: Department of Clinical Chemistry, H.d.K. Hospital, Oldenzaal, The Netherlands.

WANG, R.P. Preliminary study on the relation between "line of ganyin" and hemorheology in patients with primary liver cancer. Chung Hsi I Chieh Ho Tsa Chih 7: 734-735, 1987.

Key words: blood viscosity, liver neoplasms, hematocrit (English abstract) No address available.

ZANNAD, F.*, VOISIN, P., BRUNOTTE, F., BRUNTZ, J.F., STOLTZ, J.F. and GILGENKRANTZ, J.M. Haemorheological abnormalities in arterial hypertension and their relation to cardiac hypertrophy. J. Hypertens. 6: 293-297, 1988.

Key words: blood viscosity, erythrocyte aggregation, erythrocyte deformability, hypertension

Address for reprints: Service de Cardiologie, C.H.U. Nancy, France.

ZONDERVAN, H.A.*, OOSTING, J., SMORENBERG-SCHOORL, M.E. and TREFFERS, P.E. Maternal whole blood viscosity in pregnancy hypertension. Gynecol. obstet. Invest. 25: 83-88, 1988.

Key words: blood viscosity, hypertension, cardiovascular pregnancy complications

Address for reprints: Department of Obstetrics and Gynecology, University of Amsterdam, The Netherlands. 